度の少い第 96 図及び同様のものを䉼に作つて行つたので愦 洷范 1\% 以内に止める事が出来た。徒て 1 - $1.5 \%$ の間にあ

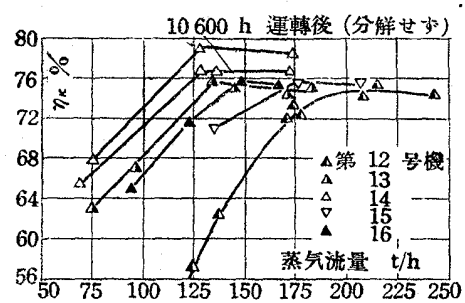

95 图 AEG 街動補别タービン の軸接手に去ける效率

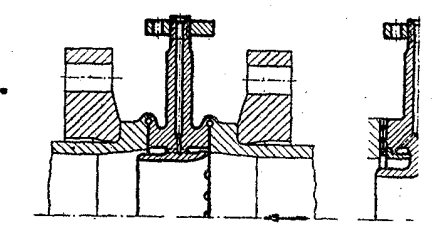

第 96 図 パッキン然しのフレン ジ掕手を有する輸狀窑ノズルの一 例

ふ、犲根の形の短維、 先端隚間の狹め、灵 根表面の粗き等の影 響、2.5\%程度の補强 線の影響等学明らか にする事が出未た。 この結果現はれた羊 の絞り損失、パッキ ン漏洩損失の過大な もの忞改食して效率 を 3〜6\% がた高め得 たものもある。通過蒸 氝平均体䅡を增すと效 棌が增し、その程度は 体秷を2偣にすると 2 \%位である。背匡 16 〜20 atm のものは4 6 atm のものより幾分

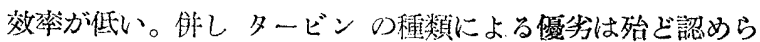
れない。

(谷村正義)

\section{[69] 原動所の修理作業}

[V. Edler, Archiv f. Wärmewirts, u. Dampfkesselw.*, 1939-11, Bd. 20, Ht. 11, 真 277 - 281, 㱔 2] 発琵所○重

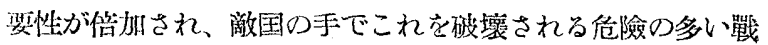
特にあつては、その修理を迅速に邆行することが特に大切で ある。單時下の修理作栄の基本は矢張り平時の経驗であるが、 唯、悠理を迅速に行ふことが第一しなり、その経済関係は第 二となる。これに関して必装しされる物的並に人的整備の開 題が詳細に論じてある。

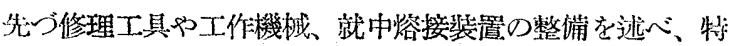
に大都會や工埸地带以外にある発電㹞でこれて充笑して置く 必装があると强調してるる。

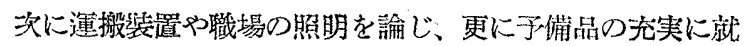

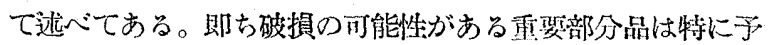

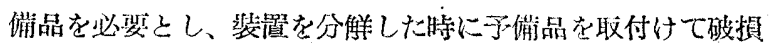
部分品を炆外し、後者は留置組立終了後に修瑟する様にすな。 又、或部分品は值に取付けて楩用出来る様に于組立て〉お く。これ等の部分品には規格統一が普及してるると健利だが 遗憾乍ら登電所関係は少し立痋れの分保である(1)。個々に就 て云へば、タービン では軸受、パッキン、弁、調整弁及び（特 に必要ある場合には）犲根の子備品を凖備し、同一型式のタ ービンが多数ある場合には組上つた回轉子 1 䈅も予備とし ておく。復水器では復水器管取替の見込ある場合にはこれも

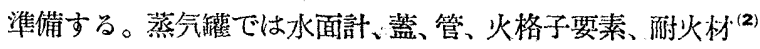
の一䚚を必贸とし、その他一般にパッキン類を判然と分類 して大簐しておく。

(1) 日本機线学會誌、43，274，(炤 15-1)，摘鑥 [7].

(2) H本機掝学會誌、42,272, (昭 $14-11$ ), 摘錄 [164]

㗱 利 15 年 2 月了

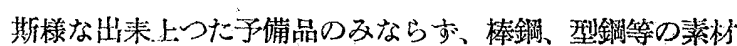
や牛製品も必要であり、文破損品を他の用途に利用方方方法 等が說明してある。特に管は種々の寸法のものを用意して、

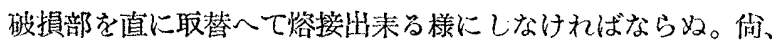
大き舞ガラス等も用意した方が宜しい。

以上の物的整備と並んで人的整㣁も必贸である。

先つ修理理恃、特殊の場合以外妒製造會社の組立職工に賴 らす、発電所自体の该事員で組織しておく方が宜しい。斯粎

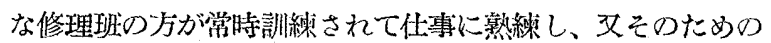

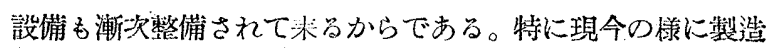

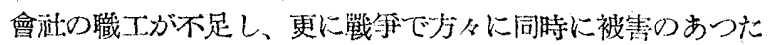
洔には到底會社の組立職厂岕待つことは出来收から向更所内 の組織が必要である。

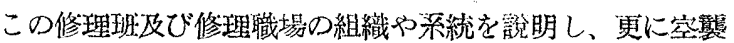

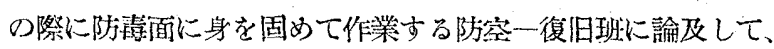
この構成並に就業洔間に就て述へ、最後に戰争て蒙名被害の 程度は予断を部ざれ好が、戰時下で特に重要な電力位給を艾

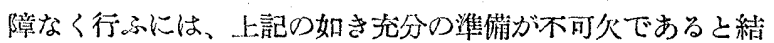
論しておる。

(高橋 安人)

\section{[70］発電所の物上及び運搬機械電気裝置}

[H. Hootz, Archiv f. Wärmewirts. u. Dampfkesselw.*, 1939-11, Bd. 20, Ht. 11, 頁 283 287, 図 8] 今日の原動 所が全能力を発旉するには、所内の物上及び薄搬機㭜が完全 に動作することが必要である。斯梯な見地からその電穴装置 が機栈技衔者向きに說明しておる。即ち先づ管動機を用途上

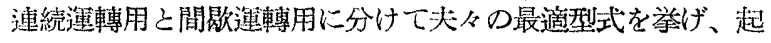
重機数、石虾匴搬設供、ベルトコンベヤ類の操作方式が述へ てある。

(高橋安人)

\section{[71] 段落美の計算法}

[W. Rohrbach, Archiv f. Wärmewirts. u. Dampfkesselw.*，1939-11，Bd. 20， It. 11，頁 293 295，図 5, 溒 3]

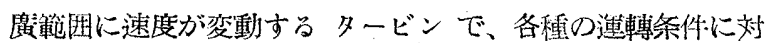
方る落差分布を計算する方法は锺々ある。斯様な落差分有を

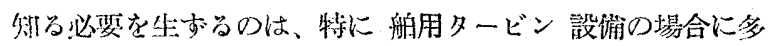

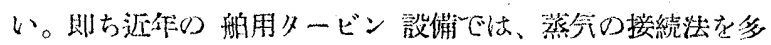

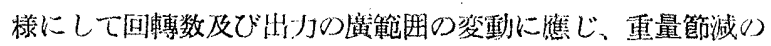
ために大抵限度型とするから、設計者は蒸气流動並に犲根の 强度の点から、各種の蒸兮消費量、速度、蒸气接繶方式に対方 る段落差を求めなければなら特に小容量 タービンの高 现及び中王車室で閒題となる旸根の曲げ應力計算には $G h_{0} / u$ (但し $G=$ 蒸氛流量、 $h_{0}=$ 段の断熱的熱洛渼、 $u=$ 冈周速度) が基礎上なり、各種の渾轉条件に対古る殷落差を知つて始め て最大礁力が求められる訳である。

この埸合、陸上用タービンで行はれるやうに、蒸気量の円 錐の法則を用ひて車室閒のE力を計賏するだけでは正確を久 く。周知の Stodola の $v^{2}$-法は、段数の多い反動式の舶用 タービンでは煩雜に先する。玆に衝動段の場合に $\sqrt{p_{1} / v_{1}}$ $=f(G, F)$ (但し $p_{1}=$ 初)正、 $v_{1}=$ 初の比体稖、 $F=$ 固定旸根の 
最小断面積）から段落差が計算される様に、反動段の埸合に もこれを穊單正確に求める方法の必要があり、止てれれを提 亦古な。

一般に段群に対するパ ーソンス定数 $\omega の$ 冦義か B、次式が成立つ。

$\omega h_{0}=u^{2}$

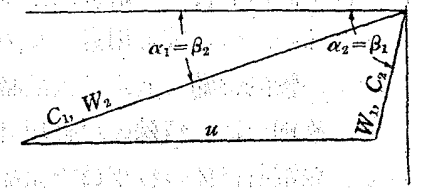

第 97 图、六口及び出口 速度線図

他方、連続の条件を回軖 犲根出口に燠用して、

$$
\frac{c_{2 a}}{u}=\frac{w w_{2} \sin \beta_{2} \sqrt{\omega h_{i}}}{u}=\frac{\tau G v_{2}}{\pi D L}
$$

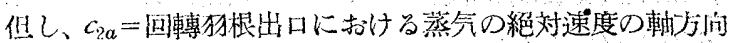
分速度、 $w_{2}=$ 之の蒸气の相対速度、 $v_{2}=$ 之の比体積、 $\beta_{2}=$ 回轉坊根の出口角、 $\div=1 \cdot 10 \sim 1 \cdot 15=$ 㷋まりの係数、 $D=$ 狗根

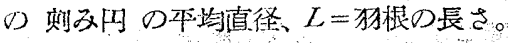

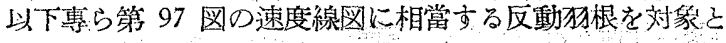
音れば、各犲根列の熱沿差は $h_{0} / 2$ だから、

$$
w_{2}=91 \cdot 5 \psi \sqrt{\frac{h_{0}}{2}+\frac{A w w_{1}^{2}}{2 g}}
$$

但し、 $\phi=$ 速度係数、 $w_{1}=$ 回轉狗根大口の蒸罙の相対速度。

然るに $\varepsilon=\sin \beta_{2} / \sin \beta_{1}$ とおけば速度線图から $w_{1}=\varepsilon \approx v_{2}$ ビから、

$$
\begin{aligned}
& w_{2}=K \sqrt{h_{0}} \ldots \ldots \ldots \ldots \\
& K=91.5 \psi \sqrt{\frac{1}{2\left(1-\psi^{2} \varepsilon^{2}\right)}}=f\left(\psi, \beta_{1}, \beta_{2}\right)
\end{aligned}
$$

(2)，(4)，(5) 式から、

$$
h_{0} \sqrt{\omega}=\frac{\tau G v_{2} u}{K \pi D L \sin \beta_{2}}
$$

(1)，(6) 式から $h_{0}$ 芯涓去すれば、

$$
\begin{aligned}
& \omega=\left(B, v_{2}\right)^{2} \ldots \ldots \ldots \ldots \\
& L=\frac{K \pi D L u \sin \beta_{2}}{\tau G}
\end{aligned}
$$

$u$ 上 $G$ 变変数と方る $B$ は、各運轉条件に対し、計算さ れるから、(7) 式で $\omega$ が求められ、徉て (1) 式から $h_{0}$ が制 明する訳である。この計算は実際に法次の様に行はれる。先 づ慓準条件下に执けるタービン内蒸气通路断闻積が既定な
らば、各種の接続を行ふ各負荷に対する出入口蒸気圧力が、 溫度修正をした蒸气量门錐の法則 (Flïgel の所謂 量と圧力 の方程式)から計算される。これから、経驗上の效率曲線ク

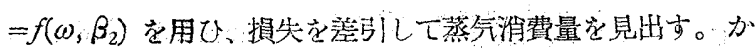
くて車窒出大口的蒸気压力、溫度、ェンタルピ、比体積が制 明古れば、 $i-s$ 線図に狀態線空假想して体積曲線 $v_{2}=f(H)$ (但し $H=\Sigma h_{0}$ ) が描かれる。文 (8)式から各段の Bが求め られる。

然る後 $v_{2}$ が既知の最終段（主番目）から本筋の計算を始 める。即ち連続の条件汇基つくく $c_{2 a}$ から $c_{2}$ 算出して 流出

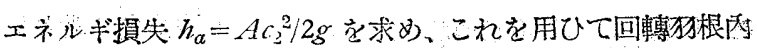
の最終蒸穴狀態范知れば、第 $z$ 段に対すっ $B_{z}, v_{2}(z), H_{z}$ が 刵明する。然らば（7）式㳖り、 $\omega_{z}=\left\{B_{z} / v_{z}(z)\right\}^{2}$ であるか

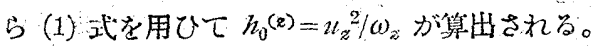

徉第 $(z-1)$ 段迄に充賞され㸓落差は $H_{z-1}=H_{z}-h_{0}(z)$ "

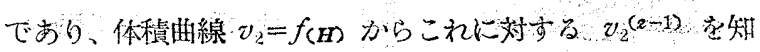
り、 $B_{z-1}, \sigma_{2}^{(z-1)}, H_{z-1}$ を用ひて $\omega_{z-1}, h_{0}^{(z-1)}$ を求める。 以下同様な手続を繰返して第10埊の様に計具を進める。この 計算の最後の段階即ち第 0 段（第 1 段固定旸根入口）だは $H=0$ でなければなら妨。この案件が不成立ならば最初に假 定した茈態曲線を改めるか、蒸气量を变更して計算を繰返す。

最後に 33 段より成々高压車壆に就て詳細な計算例が誉げ てある。

(高橋宛人)

\section{[72] 英国の霓気事業}

[R. Boye, Archiv f. Wärmewirts. 1. Dampfkesselw.*, 1939 11, Bd. 2o, Ht. 11, 頁 298～299, 図 2, 表 1] 英国 の電气事業の組織とグリッドの特色、1938 年現在の容量と 発電力量、之の效桼、特心 1936 年以後には炭價が高くなつ たために電分料金が再び高くなつたこと等の概要が記してあ 吕。

(高橋 安人)

\begin{tabular}{|c|c|c|c|c|c|c|c|c|c|}
\hline 1 & 2 & 3 & 4 & 5 & 6 & 7 & 8 & 9 & 10 \\
\hline 段 & $\beta_{2}$ & $D$ & $\begin{array}{l}L \\
\mathrm{~min}\end{array}$ & $\mathrm{~m}$; $\mathrm{s}$ & $\begin{array}{l}B \\
\text { (8) 试 } \\
\text { に依る }\end{array}$ & $\mid \begin{array}{c}v_{2} \\
\text { 体積数線に依る } \\
\mathrm{m}^{3} / \mathrm{kg}\end{array}$ & $\left\{\begin{array}{c}\omega=\left(B ; v_{2}\right)^{2}=\{(6)(7)\}^{2} \\
\mathrm{~m}^{2} \mathrm{~s}^{2} \quad \mathrm{~kg}, \mathrm{kcal}\end{array}\right.$ & $\begin{array}{c}h_{0}=u^{2} / \omega=(5)^{2} /(8) \\
k \mathrm{kcal} \mathrm{kg}\end{array}$ & $\begin{array}{c}H=H_{z}-\Sigma h_{0} \\
\text { 低压側加 } 5 \\
\mathrm{kcal} / \mathrm{kg}\end{array}$ \\
\hline 0 & - & - & - & - & - & - & - & - & $H=H_{1}-h_{0}^{(n)}=0$ \\
\hline $\begin{array}{c}1 \\
z-1\end{array}$ & $\left|\begin{array}{c}\beta_{2}^{(1)} \\
\beta_{2}^{(2-1)}\end{array}\right|$ & $\begin{array}{c}D D_{1} \\
D D_{z-1}\end{array}$ & $\begin{array}{c}L_{1} \\
L_{z-1}\end{array}$ & $u_{1}$ & $\begin{array}{c}B_{1} \\
B_{z-1}\end{array}$ & $\begin{array}{r}v_{2}^{(1)} \\
v_{2}^{(z-1)}\end{array}$ & $\begin{array}{c}\omega_{1}=\left\{B_{1} / v_{2}{ }^{(1)}\right\}^{2} \\
\omega_{z-1}=\left\{B_{z-1} / v_{2}^{(z-1)}\right\}^{2}\end{array}$ & $\begin{array}{c}h_{0}=u_{1}{ }^{2} / \omega_{1} \\
h^{(z-1)}=u_{z-1}{ }^{2} / \omega_{z-1}\end{array}$ & $\begin{array}{c}H_{1}=H_{1}-h_{0}{ }^{(2)} \\
H_{z-1}=H_{z}-H_{0}^{(2)}\end{array}$ \\
\hline$z$ & $\beta_{2}(x)$ & $D_{z}$ & $L_{z}$ & $u_{z}$ & $B_{z}$ & $z_{2}^{(z)}$ & $\omega_{z}=\left\{B_{z} / v_{2}^{(z)}\right\}^{2}$ & $h_{0}^{(z)}=u_{z}^{2} / \omega_{z}$ & $H_{z}$ \\
\hline
\end{tabular}

\section{[73] 新高速高圧蒸気タービン}

[Karl Röder, V.D.I. Z**, 1939-10-28, Bd. 83, Nr. 43, 頁 1159 -1162，図 7; 表 1]：蒸気タービンの初圧が高くな るに徉ひ、タービンを少い蒸气量で效率よく働かせる事が重 㛄となりて来た。そつためには小出力タービン 文は大出力

第 10 表段落等の訫算表 